\title{
NOTE ON PLECTROPLITES AND HYPOPLECTRODES, GENERA OF SERRANOID FISHES.
}

\author{
By Theodore Gill, LL.D.
}

Mr. Boulenger, in the first volume of his excellent Catalogue of the Perciform Fishes, has accepted two later names for genera on account of imperfect data respecting earlier ones: these are Ctenolates instead of Plectroplites, and Gilbertia in place of Hypoplectrodes. It is not surprising, for the author himself had even forgotten oneHypoplectrodes.

I.

The name Ctenolates of Guinther (1871) was adopted by Mr. Boulenger, and as a synonym was noted "Plectroplites, Gill, Proc. Ac. Philad., 1862, p. 236 (no definition); Bleek. Arch. Néerl. xi,1876, p. 267.'

It is true that at the place cited by Mr. Boulenger "no definition" was given, but one was supplied later in the following terms:

The Datnia? ambigua of Richardson, which has been referred by Ginther to the genus Dules, differs from Moronopsis ${ }^{1}$ by the shorter convex anal fin, the large second anal spine, the small eyes, and the entire physiognomy. It may be called Plectroplites ambiguus.

The characters thus positively given and contrasted with those of Kuhlia or Moronopsis are sufficient to differentiate and define the genus, although the author, like Giinther and all others, was unaware of the trenchant anatomical characters further differentiating the genus from Kuhlia. The synonymy of the genus should be amended as follows:

\section{Genus PLECTROPLITES.}

Plectroplites, G-LL, Proc. Acad. Nat. Sci. Phila. 1862, p. 236 (with typonym only); 1863, p. 286 (defined).

Ctenolates, GüNthẹr, Proc. Zool. Soc. 1871, p. 320.

Datnia? sp. Richardson.

Dules sp. Günther (1859) et al.

The P. ambiguus is still the only species known.

I Moronopsis had been previously named by Gill Kuhlia, and the latter name has been adopted by Jordan and Boulenger.

Proceedings of the United States National Museum, Vol. XVIII-No. 1082. 


\section{II.}

The name Gilbertia of Jordan and Eigenmann was adopted by Mr. Boulenger ${ }^{1}$ in place of Hypoplectrodes, because the latter was supposed to have "no definition." On the page referred to by Mr. Boulenger, indeed, no definition was given, but later (in 1871) Professor Poey, to whom I had indicated the characters in response to an inquiry for them, gave them in a memoir entitled "Genres des Poissons de la Faune de Cuba appartenant à la Famille Percida, avee une Note d'introduction par J. Carson Brevoort." 2 Prof. Poey's diagnosis was as follows:

Le genre Hypoplectrodes a été proposé par Mr. Gill, Proc. Acad. Phil., 1862, p. 236, pour le $\mathrm{Pl}$. nigro-rubrum, C. et V. Il est plus allongé que le Pl. serratum; les dentelures du bord montant du préopercule sont plus fines; il n'y a au bord inférieur que deux pointes dirigées en avant, dont l'une à l'angle. D. 10,17; A. 3,8.

I have to confess that I myself had forgotten having named this genus, or at least failed to connect with it the Plectropoma huntii of Hector of New Zealand, and consequently adopted the name Gilbertia of Jordan and Eigenmann who had overlooked the previous proposition of the genus by Gill and Poey.

The facts of the ease, then, are expressible in the following synonymy:

\section{Genus HYPOPLECTRODES.}

Hypoplectrodes, Gill, Proc. Acad. Nat. Sci. Phila. 1862, p. 236 (with typonym only) (1862)._-Poex, Ann. New York Lyc. Nat. Hist., X, p. 45, 1871 (defined).

Gilbertia, Jordan \& Eigenmann, Bull. U. S. Fish Comm., VIII, p. 346, 1890.

The species of Hypoplectrodes, according to Mr. Boulenger's ${ }^{3}$ views, are four in number, viz:

1. H. semicinctus $=$ Plectropoma semicinctum CV.=P.huntii, Hector. South Australia, New Zealand, Chile.

2. H. annulatus $=$ Plectropoma annulatum, Günther. South Australia.

3. H. nigroruber.

South Australia.

4. H. (?) armatus = Serranus armatus, Castelnau.

Australia (Swan River).

It may be added that the name Gilbertia was also given in $1891^{4}$ by Lord Walsingham to a genus of pterophoroid lepidopters.

${ }^{1}$ Vol. I, p. 306.

${ }^{2}$ Annals of the Lyceum of Natural History of New York, X, pp. 27-79.

${ }^{3}$ Vol. I, pp. 306-309.

${ }^{4}$ Ent. Monthly Mag. (2), II, p. 259. 


\section{$2 \mathrm{BHL}$ Biodiversity Heritage Library}

Gill, Theodore. 1896. "Note on Plectroplites and Hypoplectrodes, genera of serranoid fishes." Proceedings of the United States National Museum 18, 567-568. https://doi.org/10.5479/si.00963801.18-1082.567.

View This Item Online: https://www.biodiversitylibrary.org/item/32799

DOI: https://doi.org/10.5479/si.00963801.18-1082.567

Permalink: https://www.biodiversitylibrary.org/partpdf/5724

\section{Holding Institution}

Smithsonian Libraries

\section{Sponsored by}

Smithsonian

\section{Copyright \& Reuse}

Copyright Status: NOT_IN_COPYRIGHT

This document was created from content at the Biodiversity Heritage Library, the world's largest open access digital library for biodiversity literature and archives. Visit BHL at https://www.biodiversitylibrary.org. 